\title{
Cinacalcet Hydrochloride
}

National Cancer Institute

\section{Source}

National Cancer Institute. Cinacalcet Hydrochloride. NCI Thesaurus. Code C47450.

The orally bioavailable hydrochloride salt of the calcimimetic cinacalcet. Cinacalcet increases the sensitivity of calcium-sensing receptors on chief cells in the parathyroid gland to extracellular calcium, thereby reducing parathyroid hormone (PTH) secretion. A reduction in PTH levels inhibits osteoclast activity, which may result in a decrease in cortical bone turnover and bone fibrosis, and normalization of serum calcium and phosphorus levels. In addition, by reducing PTH levels, cinacalcet may reduce PSA levels; PTH appears to raise PSA levels and may increase prostate cancer cell growth. 